\title{
POPULAR SUPPORT FOR DIRECT DEMOCRACY
}

\author{
Todd Donovan and Jeffrey A. Karp
}

\begin{abstract}
The expanding use of direct democracy in many established democracies reflects a desire to provide citizens with more opportunities to be involved in the political process. These changes are assumed to be embraced by those who demand greater citizen involvement, though the underlining motivation remains unclear. One theory assumes that support is likely to come from citizens who have a deep interest in politics and are politically active. Another theory offers a contrasting view, claiming that those who find themselves on the periphery of politics, and are largely disenchanted, find such proposals attractive. We examine these theories drawing on public opinion surveys from six established democracies. We find that younger citizens and those who are more interested in the political process are more supportive of direct democracy, while political disaffection has a less consistent impact.
\end{abstract}

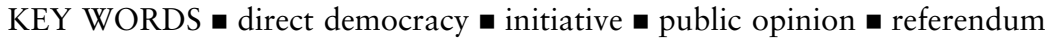

The use of direct democracy at the national and sub-national level has expanded substantially since 1970 in many established democracies. This expansion has taken the form of more frequent direct election of local officials, greater popular influence over party affairs and greater use of local and national referendums (Scarrow, 2001). Although representative democracy has not been supplanted by direct democracy, the texture of representative democracy is changing as citizens assume a more direct role in affecting parties and government. In this article, we use public opinion data to examine support for the use of the referendum and initiative in order to better understand which citizens might embrace reforms that expand direct democracy. 


\section{Expansion of Direct Democracy}

Several established democracies began granting jurisdictions use of local referendums in the past three decades, while other nations with a history of local referendum use, such as New Zealand and Canada, expanded their use of national referendums during this period (LeDuc, 2003). At least 29 referendums on European integration have been conducted across Europe (Hug, 2002), and the number of initiatives introduced by citizens has increased in Italy and Switzerland, the two European nations with constitutional provisions for initiatives (Setala, 1999; see also Butler and Ranney, 1994). Although Switzerland remains the most directly democratic polity among advanced democracies, Austria, Canada, New Zealand and Italy also have political institutions that provide for substantial direct citizen participation (Scarrow, 2001). Germany, while not reaching Swiss levels of direct democratic practices, has had one of the most dramatic increases in direct participatory institutions since 1970 (Scarrow, 2001: 658-9).

There are several explanations for this growing use of direct democracy that are based on assumptions about specific groups of citizens who might find direct democracy appealing. Some see the trend toward greater direct citizen influence over party nominations, more frequent use of initiatives and referendums, and direct election of local officials as the result of an elite response to popular demands for new forms of participation (Budge, 1996; LeDuc, 2003: 30). Research from Norris (1999) and others (Inglehart, 1999) suggests that these demands come from politically cynical 'critical' citizens who are losing confidence with representative government and conventional modes of politics, but yet retain a strong commitment to the principles of democracy.

A related explanation places expanded use of direct democracy in the context of a social trend toward 'post-materialist' expectations about a larger role for citizens in government (Inglehart, 1977), a corresponding decline in the propensity of citizens to defer to authority (Inglehart, 1990) and an 'unfreezing' of political alignments and institutions (Bogdanor, 1994). Dalton (1984) and Inglehart (1990) emphasize that 'cognitive mobilization' has led to greater demands for public access to governmental decision-making processes. From a temporal perspective, the rise of direct democracy generally, and initiative and referendum use specifically, corresponds with a rise in the political resources and skills of the electorate. These trends suggest that citizens with greater interest in politics may thus desire greater participatory democracy. Others note that political parties, at least in Germany, embraced direct democracy in intra-party affairs with the hope that the practice might stem the decline in mass participation in traditional politics by making such participation more appealing to citizens attracted to unconventional forms of participation (Scarrow, 1999). A common theme to these explanations is that one force behind demands for greater use of initiatives and referendums is citizens 
who are relatively enthusiastic about participation and relatively interested in political affairs.

Another perspective links the expansion of direct democracy to a rise in dissatisfaction with governments, but a disaffection that corresponds with either a lack of enthusiasm for classic democratic principles, or with a lack of interest in participatory politics. In their study of Germany, Dalton et al. (2001: 150) contend that the greatest popular support for direct democracy 'is located among citizens at the periphery of politics - the less interested and the less informed, and the adherents of extreme parties'. They worry that direct democracy might encourage the 'nativist and populist' tendencies that exist in contemporary Europe. There are, indeed, many right-wing populist parties that base their legitimacy on their ability to speak for 'ordinary people' (Canovan, 1999), and there is evidence that populist parties' candidates and leaders are supportive of initiative and referendum use (Bowler et al., 2003).

Hibbing and Theiss-Morse (2001) also argue that public enthusiasm for populist reforms in America does not mean that the mass public desires greater direct responsibility for governing. Rather, citizens want decisionmaking processes to represent a balance between elected officials and 'ordinary people', but they perceive that the process of governing is dominated too much by office-holders. Their support for direct democracy, then, reflects a dissatisfaction with the behaviour of their representatives, rather than an interest in greater participatory democracy per se. Norris (1999) and Pharr and Putnam (2000) may also be read as suggesting that disaffected citizens do not want more democracy, but that they simply want democracy to work better. Hagen and Lascher (2004), in contrast, note that popular support for direct democracy (the popular initiative) reflects citizen confidence in the character of voters, rather than hostility to politicians.

\section{Popular, But with Whom?}

Despite this variety of explanations about public support for direct democracy, there are few studies designed with the specific goal of generating and testing hypotheses about which citizens support direct democratic reforms, and even fewer that do so in a comparative framework. Most of the studies discussed above focus on general questions of citizen confidence in government (e.g. Norris, Inglehart, Hibbing and Theiss-Morse), partisan dealignment (Dalton, 1984), or on the nature of institutional changes associated with direct democracy (e.g. Budge, Scarrow). As such, these studies offer important insights into political change, but they make no attempts at identifying the supporters of direct democracy in the mass public.

There is no shortage of evidence that direct democracy - specifically the initiative and referendum - are popular in a variety of settings. Numerous authors have reported results of surveys that demonstrate widespread popular support for the use of referendums and popular initiatives in the 
United States (Bowler and Donovan, 1998: 47; Cronin, 1989: 174-80; Hagen and Lascher, 2004), Canada (Mendelsohn and Parkin, 2001: 4; O'Neill, 2001) and in New Zealand (Karp and Aimer, 2002: 150). In Sweden, Norway and Finland, attitudes toward the use of referendums also appear to be largely supportive, albeit with some limits (Gilljam et al., 1998). One consistent finding from these opinion polls is that there is very little opposition to the use of initiatives and referendums: opinions tend to distribute such that a substantial majority approve, with most remaining respondents being more indifferent than opposed. None of these studies develop models of support for direct democracy, and only two (Dalton et al., 2001; Gilljam et al., 1998) make any attempts to assess support beyond a single jurisdiction.

\section{Hypotheses About Support for Direct Democracy}

Three previous studies provide us with some structure for organizing hypotheses about who supports direct democracy. The Dalton et al. (2001) investigation of support for direct democracy in Germany proposed two broad explanations: one that assumes politically interested citizens support direct democracy, and another that assumes that politically disaffected do. Gilljam et al. (1998) provide similar categories of explanation in their study of support for referendum use in Finland, Norway and Sweden. Likewise, the Craig et al. (2001) study of opinions about direct democracy in Florida used similar categories to organize their explanations. Dalton et al. (2001) provide what they labelled a 'New Politics' explanation, with a rival political disaffection explanation, while Craig et al. (2001) used a similar dichotomy but labelled their explanatory categories as a cognitive mobilization explanation of support for referendum use, countered with a political disaffection explanation of support. Gilljam et al. (1998) group their hypotheses into a similar dichotomy, labelling their categories as a political competence hypothesis and a distrusting citizen hypothesis. Each study uses similar measures to test their hypotheses.

The Gilljam et al. (1998), Dalton et al. (2001) and Craig et al. (2001) studies each found no support for the cognitive mobilization explanation, although none of these studies used multivariate models to test their hypotheses, and the analysis in each was largely limited to data from few jurisdictions. Craig et al. (2001) concluded that neither the cognitive mobilization nor political disaffection explanations had much utility in the Florida case, whereas Dalton et al. (2001) concluded that political disaffection was largely responsible for support for direct democracy in Germany, and, by extension, Europe. Gilljam et al. (1998) found it surprising that their results ran in the opposite direction as predicted by the political competence hypothesis, but also found, like Dalton et al. (2001), that the distrusting citizen hypothesis had utility in the Nordic case. 
Using data from a larger set of nations, we can assess how we might be able to make generalizable conclusions about support for direct democracy. We make use of opinion data from several nations in order to estimate multivariate models that can compare the relative explanatory power of the New Politics/cognitive mobilization thesis to the political disaffection thesis. The cognitive mobilization account predicts a link between having greater political resources - such as higher education, political skills or interest in politics - and support for direct democracy. The cognitive mobilization hypothesis is based on the assumption that citizens who have the requisite political resources for navigating political issues are more capable of making their own political decisions (Dalton, 1996: 21) and thus more likely to embrace reforms that give them greater opportunities to express their choices. The 'New Politics' element extends this explanation to predict that support for direct democracy should also be greater among social and political groups such as the young and supporters of Green parties.

The disaffection explanation predicts a link between political cynicism, or a 'loss of public confidence in traditional democratic structures' (Craig et al., 2001: 25), and support for direct democracy. Dalton et al. (2001: 148) conclude that 'Europeans have grown less satisfied with the institutions of representative democracy and the way that the democratic process works', and suggest that calls for direct democracy reflect popular disaffection with party-based government.

\section{Cases and Data}

We make use of several public opinion surveys to examine the structure of attitudes about direct democracy in order to test these hypotheses. We utilize data from six different nations, each of which makes use of direct democracy in different ways, in order to see how much we might be able to make cross-national generalizations about the nature of support for direct democracy. The set of nations we examine is limited to established democracies, and defined in large part by the convenience of where we were able to place questions on national surveys or where we were able to obtain existing survey data that included questions about referendums.

Despite this selection method, our cases provide a range of contrast in terms of region and in terms of use of direct democracy. The cases we examine are not easily categorized in terms of how much their citizens have exposure to the initiative and referendum. Switzerland stands alone as making frequent use of direct democracy. Canada and New Zealand have a history of modest use of direct democracy, while these Scandinavian nations have a history of more limited practice with direct democracy (Budge, 1996; Gallagher and Uleri, 1996; LeDuc, 2003: 31; Scarrow, 2001). Our cases include: 
1 Switzerland. Switzerland, which by several accounts has the most unmediated democratic institutions of established democracies. Apart from California, Switzerland makes greater use of citizen-initiated referendums than any other major polity. We measure approval of direct democracy with a 2003 Swiss Eurobarometer survey that asked respondents how important direct democracy was to the future of Switzerland. Approval of direct democracy is represented by responding that it is very important.

2 New Zealand. New Zealand, which has long used local referendums, adopted electoral reforms via national referendums in the 1990s, and adopted a process for national advisory citizen-initiated referendums in 1993. We placed questions on the 1999 New Zealand Election Study asking if citizens thought that referendums and citizen-initiated referendums were good things or bad things, or did not make much difference. Approval of direct democracy is represented by the response that initiatives are good things.

3 Canada. Canada, which has a history of referendum use at the local and provincial level, has a history of limited use of national constitutional referendums, most notably the 1992 referendum on a Constitutional accord about the status of Quebec. Canada also has a history of populism (Laycock, 1990) and adopted provisions for direct initiative in some provinces (Ruff, 1993), although that process never took root. We measure approval of direct democracy using a question from the 2000 Canadian Election Study that asked how often referendums should be held on important or controversial issues. Greater approval of direct democracy is represented by the respondents who agreed that referendums should be held more frequently.

4 Sweden. Sweden also allows for constitutional referendums, though none have ever been conducted. Six referendums have been held in Sweden: on such topics as whether to adopt the euro (2003), to join the European Union (1994), reliance of Nuclear Power (1980), pensions (1957), changing from left-hand or right-hand traffic (1957) and prohibition (1922). However, none of these referendums were binding, but rather advisory. Sweden also has a seldom-used system of local referendums similar to Finland.

5 Finland. Finland authorized local referendums in 1990. Local referendums qualify with signatures from 5 percent of those entitled to vote and with the authorization of the local council. These are seldom used, however. It also has procedures for optional advisory legislative referendums. A referendum on EU membership was held in 1994.

6 Norway. Norway's use of the referendum is limited. The two most recent cases concerned EU membership held in 1994 and 1972. In 1919, a referendum was held on prohibition and in 1905 voters decided two referendums, one that was demanded by Sweden dealing with Norwegian independence and the other to decide whether Danish Prince Carl should take over the Norwegian throne (both of which passed overwhelmingly). We measure support for direct democracy in these Nordic nations with a 
question on the 1994 European Referendum Study that asked how often referendums should be held. Respondents saying 'more referendums in the future' are coded as being more approving of direct democracy.

Table 1 displays the responses to these survey questions in each nation. It must be stressed that our measures of approval of direct democracy are slightly different in each nation; however, each question does capture a sense of whether a person supports the practice of using referendums, and/or using referendums more frequently. We find substantial support for the occasional or frequent use of direct democracy in each nation. Majorities of New Zealand and Swiss respondents, respectively, agreed that initiatives and referendums were 'good things' and a 'very important' political institution for the future. Likewise, a majority of Canadian respondents agreed that referendums should be held 'regularly' or 'occasionally', and majorities of Finns, Norwegians and Swedes agree that referendum use should be

Table 1. Support for direct democracy in six nations

\begin{tabular}{|c|c|c|}
\hline & Survey question & Responses \\
\hline New Zealand & $\begin{array}{l}\text { Referendums and initiatives a good thing } \\
\text { Referendums and initiatives a bad thing } \\
\text { Referendums and initiatives make no difference }\end{array}$ & $\begin{array}{l}66.4 \% \\
1.0 \\
34.0 \\
(\mathrm{~N}=5,032)\end{array}$ \\
\hline Switzerland & $\begin{array}{l}\text { Direct democracy very important } \\
\text { Direct democracy is of sufficient importance } \\
\text { Direct democracy is not really important } \\
\text { Direct democracy is not at all important }\end{array}$ & $\begin{array}{l}64.8 \% \\
31.0 \\
3.9 \\
0.3 \\
(\mathrm{~N}=1,016)\end{array}$ \\
\hline Canada & $\begin{array}{l}\text { Use referendums regularly on important issues } \\
\text { Use referendums occasionally } \\
\text { Use referendums rarely } \\
\text { Use referendums never }\end{array}$ & $\begin{array}{l}20.7 \% \\
42.0 \\
24.7 \\
9.3 \\
(\mathrm{~N}=2,860)\end{array}$ \\
\hline Finland & $\begin{array}{l}\text { Have more referendums in the future } \\
\text { Be modest with referendum use } \\
\text { Have no referendums }\end{array}$ & $\begin{array}{l}45.5 \% \\
49.2 \\
5.3 \\
(\mathrm{~N}=1,525)\end{array}$ \\
\hline Norway & $\begin{array}{l}\text { Have more referendums in the future } \\
\text { Be modest with referendum use } \\
\text { Have no referendums }\end{array}$ & $\begin{array}{l}31.5 \% \\
63.9 \\
4.6 \\
(\mathrm{~N}=2,878)\end{array}$ \\
\hline Sweden & $\begin{array}{l}\text { Have more referendums in the future } \\
\text { Be modest with referendum use } \\
\text { Have no referendums }\end{array}$ & $\begin{array}{l}30.9 \% \\
62.4 \\
6.7 \\
(\mathrm{~N}=1,996)\end{array}$ \\
\hline
\end{tabular}


regular or at least modest (see Appendix for question wording). In each of these nations, very few respondents agree that referendums are 'bad things' or that they should never be held.

Although these results demonstrate consistent support for direct democracy and the use of referendums, they should not be seen as reflecting unmediated enthusiasm for frequent use of referendums in each nation. The modal responses in Canada, Finland, Norway and Sweden suggest stronger support for occasional use of referendums than for increased use. In the next section, we model variation in these attitudes in each of these nations.

\section{Models of Support for Referendum Use}

We test the hypotheses discussed above by estimating two sets of models that use similar variables in each nation. The first set includes variables that we use to represent elements of the cognitive mobilization thesis. Given the differences in education systems across countries, we use a simple dummy variable to represent educational attainment where 1 represents those with a university degree and 0 represents those without. Following the cognitive mobilization/political competence thesis, we expect those with higher education to have greater political competence and resources, and thus would be more comfortable negotiating referendum decisions and more supportive of referendum use. The cognitive mobilization model includes a measure of political interest. The variable has been standardized to range from 0 to 1 with higher values representing greater interest. ${ }^{1}$ To capture political motivation, we rely on whether a respondent reports voting in the last national election. The cognitive mobilization and 'New Politics' concepts discussed above lead us to expect that those who are more interested in politics, as well as those who voted in the last election, are engaged with democratic participation (and perhaps even seek more avenues of participation) and thus more likely to support referendum use than nonvoters and those who are less interested in politics. These models include controls for gender and age. Age has been used as a test of the New Politics thesis, with the assumption being that younger voters are more likely to hold post-materialist values and to desire more say in politics via direct political action (Dalton et al., 2001: 146). Of course, the effect of age can also represent other attitudinal and behavioural differences across generations and cohorts, including weaker attachments to established political institutions (such as parties and party systems) among the young.

The second set of models includes variables that are used to represent elements of the political disaffection thesis. One of the most frequently used indicators of dissatisfaction is one that asks respondents to evaluate their satisfaction with the way democracy works in their country. The item is intended to measure support for the political system and is assumed to be an indicator of the diffuse support necessary for institutions to build 
legitimacy (Karp et al., 2003). The variable has four categories ranging from 'very satisfied' (0) to 'not at all satisfied' (1). Unfortunately, no comparable measure of dissatisfaction with democracy is available in the Nordic countries. As a substitute, a measure of disaffection with the political process is captured by whether respondents believed that their MPs were 'out of touch'. The item has five categories but has been standardized to range from 0 to 1 . In each case, the disaffection thesis predicts that people holding these sentiments will be more supportive of direct democracy.

Our disaffection models include variables that identify citizens who may feel excluded from the political process. Previous theory and survey results demonstrate a clear relationship between support for parties that are out of government and political disaffection - with supporters of losing parties more dissatisfied with democracy and more supportive of electoral reforms (Anderson et al., 2005). Incumbent legislators (Bowler et al., 2006), furthermore, and candidates of parties in government (Bowler et al., 2002) are also less sympathetic to referendum and initiative use, since direct democracy might weaken their (or their party's) influence over the legislative agenda. This leads us to expect that citizens who voted for losing parties are more likely to support the use of referendums as a means to challenge the influence of parties in government that they do not support. We thus include a dummy variable that represents electoral losers by identifying people who voted for a party that did not join government. Another dummy variable is included in the model to represent non-voters, leaving those who reported voting for the government parties (winners) as the reference category. Along with vote choice, those placing themselves on the far left or the far right of the ideological spectrum are represented with unique dummy variables to test if citizens located at the 'periphery of politics' (Dalton et al., 2001: 150) are engaged at all by the prospect of direct democracy. These models are also estimated with controls for age and gender. The models are estimated with logistic regression, where the dependent variable was either dichotomous (as in the case of New Zealand) or where the response categories were rank ordered (as in the case of Switzerland, for example).

\section{Results}

The results, which are reported in Tables 2 and 3, suggest that there is variation in the basis of support for direct democracy across these nations, and that generalizations made based on any single nation, or small set of jurisdictions, can be problematic. Looking first at the results for the cognitive mobilization models in Table 2, our findings provide more support for the cognitive mobilization/political competence thesis than reported in previous studies. We find evidence in New Zealand, Canada and Switzerland that support is greater among those who are more interested in politics. In New Zealand and Switzerland, support was also greater among people who 
Table 2. Cognitive mobilization model: logit coefficients

\begin{tabular}{|c|c|c|c|}
\hline & New Zealand & Switzerland & Canada \\
\hline & Estimate S.E. & Estimate S.E. & Estimate S.E. \\
\hline Age (in 10s) & $-0.07 * *(0.02)$ & $(0.04)$ & $-0.16 * \quad(0.02)$ \\
\hline Female & $-0.18 * \quad(0.06)$ & $(0.13)$ & $0.10 \quad(0.07)$ \\
\hline University degree & $0.02 \quad(0.08)$ & $0.04 \quad(0.21)$ & $-0.29 * \quad(0.09)$ \\
\hline Political interest & $0.20 * *(0.04)$ & $0.95 * *(0.32)$ & $0.32 * \quad(0.13)$ \\
\hline Voter & $0.72 * *(0.15)$ & $0.31 * \quad(0.16)$ & $-0.12 \quad(0.10)$ \\
\hline Intercept 1 & $-0.14 \quad(0.19)$ & $-5.04 * \quad(0.65)$ & $-2.68 * *(0.14)$ \\
\hline Intercept 2 & $\ldots$ & $-2.33 *(0.34)$ & $-1.15 *(0.14)$ \\
\hline Intercept 3 & $\ldots$ & $0.21 \quad(0.32)$ & $0.76 * \quad(0.14)$ \\
\hline No. of cases & 4,911 & 1,012 & 2,759 \\
\hline \multirow[t]{3}{*}{ Nagelkerke Pseudo $\mathrm{R}^{2}$} & 0.02 & 0.03 & 0.03 \\
\hline & Norway & Sweden & Finland \\
\hline & Estimate S.E. & Estimate S.E. & Estimate S.E. \\
\hline Age (in 10s) & $-0.02 * *(0.00)$ & $-0.03 * \quad(0.00)$ & $-0.02 * \quad(0.00)$ \\
\hline Female & $0.14 \quad(0.08)$ & $0.34 *(0.09)$ & $0.48 * \quad(0.10)$ \\
\hline University degree & $-0.55 * \quad(0.10)$ & $-0.39 * \quad(0.12)$ & $-0.77 * \quad(0.15)$ \\
\hline Political interest & $-0.18 * \quad(0.06)$ & $0.05 \quad(0.06)$ & $-0.08 \quad(0.06)$ \\
\hline Voter & $-0.04 \quad(0.12)$ & $-0.48 *$ & $-0.09 \quad(0.16)$ \\
\hline Intercept 1 & $-4.50 * *(0.21)$ & $(0.28)$ & $-4.17 * *(0.27)$ \\
\hline Intercept 2 & $-0.57 * \quad(0.18)$ & $(0.26)$ & $-0.94 * \quad(0.23)$ \\
\hline No. of cases & 3,281 & 1,996 & 1,517 \\
\hline Nagelkerke Pseudo $\mathrm{R}^{2}$ & 0.05 & 0.07 & 0.09 \\
\hline
\end{tabular}

$* p<0.01 ; * p<0.05$.

reported voting. The results, however, are not entirely consistent with the cognitive mobilization theory. The effects of political interest are reversed in Norway, and voters (in Sweden) are less likely to support more use of referendums than non-voters. Moreover, there is no positive effect for education in any of the country-specific models. In fact, in Canada and in all three Nordic countries respondents with university degrees are less willing to use referendums more frequently. However, if we accept the idea that age (youth) is a surrogate for post-materialist sentiments, then the New Politics variant of the cognitive mobilization thesis may also find some support here. Age is negative and significant in five of the six cases, indicating that younger respondents are consistently more supportive of direct democracy. The only exception is Switzerland, where regular use of direct democracy represents status quo political arrangements. Nevertheless, differences between younger and older citizens can be substantial. In Canada, for example, where the coefficient for age is the largest, the probability of supporting the regular use of referendums for a person of 18 years, holding all other variables constant at their mean values, is 0.27 . In contrast, 
Table 3. Disaffection model: logit coefficients

\begin{tabular}{|c|c|c|c|c|c|c|}
\hline & \multicolumn{2}{|c|}{ New Zealand } & \multicolumn{2}{|c|}{ Switzerland } & \multicolumn{2}{|c|}{ Canada } \\
\hline & Estimate & S.E. & Estimate & S.E. & Estimate & S.E. \\
\hline Age (in 10s) & $-0.04 *$ & $(0.02)$ & -0.03 & $(0.04)$ & $-0.16 * *$ & $(0.02)$ \\
\hline Female & $-0.18 * *$ & $(0.06)$ & -0.23 & $(0.14)$ & 0.13 & $(0.07)$ \\
\hline Right & 0.03 & $(0.09)$ & $0.91 * *$ & $(0.26)$ & 0.16 & $(0.10)$ \\
\hline Left & $0.25 *$ & $(0.10)$ & 0.24 & $(0.18)$ & -0.13 & $(0.11)$ \\
\hline Loser & $0.26 * *$ & $(0.07)$ & 0.10 & $(0.25)$ & $0.26 * *$ & $(0.08)$ \\
\hline Non-voter & $-0.62 * *$ & $(0.15)$ & $-0.39 *$ & $(0.16)$ & 0.00 & $(0.11)$ \\
\hline $\begin{array}{l}\text { Dissatisfaction with } \\
\text { democracy }\end{array}$ & -0.22 & $(0.18)$ & $-1.87 * *$ & $(0.44)$ & $0.66 * *$ & $(0.17)$ \\
\hline Intercept 1 & $1.00 * *$ & $(0.16)$ & -7.05 & $(0.67)$ & $-2.16 * *$ & $(0.16)$ \\
\hline Intercept 2 & & & -4.33 & $(0.36)$ & $-0.58 * *$ & $(0.16)$ \\
\hline Intercept 3 & . & & -1.79 & $(0.33)$ & $1.34 * *$ & $(0.16)$ \\
\hline No. of cases & 4,85 & & 99 & & 2,69 & \\
\hline \multirow[t]{3}{*}{ Nagelkerke Pseudo $\mathrm{R}^{2}$} & 0.0 & & 0.0 & & 0.0 & \\
\hline & \multicolumn{2}{|c|}{ Norway } & \multicolumn{2}{|c|}{ Sweden } & \multicolumn{2}{|c|}{ Finland } \\
\hline & Estimate & S.E. & Estimate & S.E. & Estimate & S.E. \\
\hline Age (in 10s) & $-0.03 * *$ & $(0.00)$ & $-0.03 * *$ & $(0.00)$ & $-0.02 * *$ & $(0.00)$ \\
\hline Female & 0.05 & $(0.09)$ & $0.29 * *$ & $(0.10)$ & $0.43 *$ & $(0.10)$ \\
\hline Right & 0.16 & $(0.14)$ & -0.24 & $(0.15)$ & -0.02 & $(0.15)$ \\
\hline Left & $0.37^{*}$ & $(0.17)$ & $0.34 *$ & $(0.15)$ & -0.19 & $(0.23)$ \\
\hline Loser & $0.23 *$ & $(0.10)$ & -0.04 & $(0.11)$ & $0.24 *$ & $(0.12)$ \\
\hline Non-voter & 0.02 & $(0.13)$ & $0.40^{\mathrm{a}}$ & $(0.22)$ & 0.11 & $(0.17)$ \\
\hline MPs out of touch & 1.57 & $(0.15)$ & $1.25 * *$ & $(0.21)$ & $1.32 * *$ & $(0.03)$ \\
\hline Intercept 1 & $-3.15 *$ & $(0.22)$ & $-3.22 * *$ & $(0.24)$ & $-2.65 * *$ & $(0.26)$ \\
\hline Intercept 2 & $0.94 * *$ & $(0.17)$ & $0.49 *$ & $(0.22)$ & $0.59 *$ & $(0.25)$ \\
\hline No. of cases & \multicolumn{2}{|c|}{2,805} & \multicolumn{2}{|c|}{1,734} & \multicolumn{2}{|c|}{1,519} \\
\hline Nagelkerke Pseudo $\mathrm{R}^{2}$ & \multicolumn{2}{|c|}{0.09} & \multicolumn{2}{|c|}{0.10} & \multicolumn{2}{|c|}{0.10} \\
\hline
\end{tabular}

$* * p<0.01 ; * p<0.05 ;{ }^{a} p=0.06$.

a 78 -year-old citizen is less than half as likely (0.12) of holding the same opinion.

While we find some support for the cognitive mobilization thesis outside the Nordic nations, we also find some support for the political disaffection thesis. As Table 3 reveals, in New Zealand, Canada, Norway and Finland, supporters of parties out of government are significantly more likely than electoral winners to approve of referendum use. Non-voters are also less likely than winners to support direct democracy in New Zealand and Switzerland. Results for our other measures of disaffection are less consistent. Dissatisfaction with democracy (or with MPs) is positively related to support for direct democracy in Canada and in two of the three Nordic nations. In Switzerland, the sign is reversed, indicating that those 
dissatisfied with the way democracy works are more likely to reject the status quo by dismissing the importance of direct democracy. Those at the extreme ends of the ideological spectrum are more likely to support direct democracy in some cases. In New Zealand, Norway and Sweden, those on the left are more likely than political moderates to support the frequent use of referendums, while those on the right are more supportive in Switzerland only.

To ease the interpretation of the logit estimates and to provide a better sense of their substantive impact, Table 4 presents the estimated probabilities for each theory. In the cases where the dependent variable is ordinal, probabilities are given for the highest category. To assess their cumulative impact, we estimate the minimum and maximum values for the set of primary variables associated with each theory. High cognitive mobilization is represented by the youngest voters who have a university degree and are most interested in politics. In comparison, low cognitive mobilization is represented by the oldest non-voters, who are the least interested in politics and who lack a university degree. For the disaffection model, estimates are presented for electoral losers who are the most dissatisfied with politics and, compared to winners who are the most satisfied. As Table 4 shows, the cumulative effects for the cognitive mobilization variables in each country produce positive and in some cases substantial effects - with the lowest estimated effect of high cognitive mobilization producing a 0.09 increase in the probability a Norwegian respondent approves of direct democracy to a high of a 0.37 increase in this probability for a respondent from New Zealand. In New Zealand, the probability of support for direct democracy increases from 0.27 to 0.64 for younger voters who are interested in the political process (as compared to older non-voters who are disinterested). In Canada, the cumulative effects of high cognitive mobilization are not as great (a 0.16 increase in probability of supporting direct democracy), given that university degrees offset the positive effects of political interest and youth.

Table 4. Probability estimates of supporting direct democracy

\begin{tabular}{|c|c|c|c|c|c|c|}
\hline & \multicolumn{3}{|c|}{ Cognitive mobilization } & \multicolumn{3}{|c|}{ Disaffection } \\
\hline & Low & High & Overall & Low & High & Overall \\
\hline Canada & 0.09 & 0.25 & 0.16 & 0.12 & 0.25 & 0.13 \\
\hline New Zealand & 0.27 & 0.64 & 0.37 & 0.67 & 0.68 & 0.01 \\
\hline Switzerland & 0.43 & 0.73 & 0.30 & 0.83 & 0.46 & -0.37 \\
\hline Norway & 0.28 & 0.37 & 0.09 & 0.12 & 0.46 & 0.34 \\
\hline Sweden & 0.19 & 0.38 & 0.19 & 0.16 & 0.38 & 0.22 \\
\hline Finland & 0.29 & 0.45 & 0.16 & 0.2 & 0.55 & 0.35 \\
\hline
\end{tabular}

Note: Cognitive mobilization estimates derived from Table 2 when age, political interest, university degree and voter vary at their $\mathrm{min} / \mathrm{max}$ values. Disaffection estimates derived from Table 3 when loser and dissatisfaction with democracy/MPs out of touch vary at their $\min / \max$ values. 
Table 4 demonstrates that the disaffection thesis produces fewer consistent effects. The effects of high levels of political disaffection in the Nordic countries are the most substantial and consistent increases in the predicted probability of supporting direct democracy: ranging from a 0.22 increase in Sweden to 0.35 in Finland. In New Zealand and Switzerland, however, although the effect of being an electoral loser is in the expected direction, dissatisfaction is not. In New Zealand, then, the cumulative effect of high political disaffection is negligible (0.01). In Switzerland, the cumulative effects of supporting losing parties and being less satisfied with how democracy is working leads a Swiss citizen to be less likely to believe direct democracy is important. This means that Switzerland is the only nation where we find respondents with the least political disaffection to be more supportive of direct democracy. This finding may be due to the particularly rare nature of the Swiss political context. Given that it is the norm for referendums and initiatives to play an important role in Switzerland, and given that Swiss parliamentary elections have little influence on the composition of government, it is not entirely surprising that those most dissatisfied with Swiss democracy are also least enthusiastic about direct democracy.

Although these results suggest support for both theories, it is evident that neither model adequately explains attitudes toward direct democracy. A pseudo $R^{2}$ is provided to illustrate the fit of the model, although such measures should be interpreted with caution (Hagle and Mitchell, 1992). Nevertheless, the fit of all of the models is rather poor, indicating that these variables alone cannot explain much of the variance in support. In assessing the relative fit of the models, the Nordic disaffection models capture the best fit but even so there is much to be explained.

\section{Discussion}

In a survey of the effects of political reforms designed to lower barriers to participation (e.g. postal voting, absentee voting, election-day registration), Berinsky (2005) notes that such reforms often have the effect of mobilizing higher proportions of interested voters than less interested ones. He finds that when rules are changed to make it easier to vote, people with higher levels of political interest are most likely to take advantage of the rule change. The less interested, in contrast, lack sufficient levels of interest to be engaged, even when barriers to participation are reduced. From this perspective, it seems plausible that when democratic institutions require additional effort from citizens, those institutions will elicit less support from people with low levels of interest in politics than from those with more interest.

For many people, the desire to participate in initiative and referendum decisions probably corresponds with some level of political interest. Perhaps we should not be too surprised, then, to find some evidence here consistent 
with the cognitive mobilization thesis. Referendums and initiatives do require that citizens make more political decisions than they would have to do otherwise, and possibly require that they must also obtain additional cues and information to make such decisions. Although there is ample evidence suggesting that readily available cues assist people in making such decisions (Bowler and Donovan, 1998; Lupia, 1994), the act of participating in a referendum nevertheless presents the citizens with additional cognitive costs of participation. Unlike previous studies of attitudes about direct democracy, some of our findings are consistent with the idea that the politically interested and politically engaged, at least in some nations, are less sensitive to such costs, and, thus, more supportive of direct democracy. These findings are also consistent with other research suggesting that referendums may encourage the politically interested and educated to turn out at elections (Donovan et al., 2005).

Results from this study also have implications for normative assessments of direct democracy. Our results provide little support for the idea that direct democracy may be used as a tool to mobilize those most peripheral to politics, nor do they demonstrate that direct democracy finds particular support on the far right of the ideological spectrum. This might be possible, but we find little support for those ideas here. This point is important. Although we do find some mixed support for the political disaffection thesis, the patterns we observe in our multivariate analysis suggest different conclusions than those reached by Dalton et al. (2001). Although we do find that frequent use of referendums had more opposition among those with a university education (in some nations), many of our multivariate findings fail to conform with the results they report from Germany and elsewhere in Europe. ${ }^{2}$

As for the threat that referendums may present to democracy, increased referendum use was more popular among people who place themselves on the far left of the ideological spectrum in more places than it was popular with the far right. In the Nordic nations, we do find that people who thought MPs were out of touch had greater support for increased referendum use, as did supporters of parties out of government, but these links between disaffection and support for referendums are not so substantial as to 'strain the fabric of democracy'. Nor do they seem a basis for fearing a 'rejection of the political status quo' that 'stands closer to the populism of Jorg Haider ... than to the Greens' ideology' (Dalton et al., 2001: 150). Moreover, our primary measures of disaffection - non-voters - and dissatisfaction with how democracy was working, fail to consistently predict support for direct democracy. Indeed, the findings reported here are consistent with another study that found supporters of populist parties failed to embrace their party's enthusiasm for initiative and referendum use. While populist candidates may preach the virtue of direct democracy, their supporters may have views about direct democracy that are not much different from supporters of other parties (Bowler et al., 2003). 
When examined through the lens of multivariate analysis across a range of nations, we find that any understanding of mass support for direct democracy is likely to be more complex - and perhaps less threatening to democracy - than that described by Dalton et al. (2001). Support for direct democracy, at least in some limited forms, is consistently high across a wide range of countries. Neither the cognitive mobilization theory nor the political disaffection theory explains much of the variance in levels of support we find in the six nations examined here. This suggests that attitudes about direct democracy are rather diffuse, reflecting a general tendency to support such devices that is shared across a broad segment of the electorate, rather than something particular to those peripheral to politics.

\section{Appendix}

\section{Switzerland}

Source: Swiss Eurobaromater 2003.

Archive: SIDOS Nesstar Server (http://nesstar.sidos.ch/).

Question: Switzerland has unique political institutions. We are going to ask about three of them. The first is neutrality, which is to say, the choice to not involve ourselves in foreign conflicts. The second is federalism, which is to say, the partitioning of responsibility between the confederation, cantons and communes. The third is direct democracy, which is to say, the right to sign petitions and initiatives and referendums and to vote accordingly. How important are these institutions for the future of Switzerland? 4 = very important; 3 = somewhat important; $2=$ not very important; 1 = not at all important.

\section{New Zealand}

Source: The New Zealand Election Study, 1999.

Archive: www.nzes.org

Question: Overall, do you think that referendums and citizen-initiated referendums are 1 = good things; 0 = bad things, or don't you think they make much difference?

\section{Canada}

Source: Canadian Election Study, 2000.

Archive: http://www.ces-eec.umontreal.ca/

Question: Do you think that referendums on IMPORTANT/CONTROVERSIAL issues should be held: 4 = regularly; 3 = occasionally; 2 = rarely; $1=$ never?

Note: Half the sample was asked the question using 'important' issues and the other half was asked using 'controversial'. Responses were nearly identical across the two samples, so they have been combined into a single measure. 


\section{Norway, Sweden, Finland}

Source: European Referendum Study, 1994.

Archive: Nordic Norwegian Social Science Data Services (http://www.nsd.uib.no/).

Question: What do you think about referendums in general? Should they be held 3 = frequently, 2 = sparingly; 1 = or never?

\section{Notes}

Authors' names are listed alphabetically; authorship is equal. We would like to thank Marshall W. Garland for research assistance.

1 In Switzerland, we rely on a question about the frequency of political discussion, as political interest was not asked of respondents.

2 For example, Dalton et al. (2001: 147) find that in Germany those with the least interest in politics are the most supportive of direct democracy. They note that the finding is consistent with an earlier finding in Finland reported by Pertti Pesonen (1994). We find, however, that political interest is more often positively associated with support for direct democracy. In Finland, the negative effect observed by Pesonen disappears in our multivariate models.

\section{References}

Anderson, Christopher J., Andre Blais, Shaun Bowler, Todd Donovan and Ola Listhaug (2005) Losers' Consent: Elections and Democratic Legitimacy. Oxford: Oxford University Press.

Berinsky, Adam J. (2005) 'The Perverse Consequences of Electoral Reform in the United States', American Politics Research 33: 471-91.

Bogdanor, Vernon (1994) 'Western Europe', in D. Butler and A. Ranney (eds) Referendums Around the World: The Growing Use of Direct Democracy, pp. 24-98. Washington, DC: AEI Press.

Bowler, Shaun and Todd Donovan (1998) Demanding Choices: Opinion, Voting, and Direct Democracy. Ann Arbor, MI: University of Michigan Press.

Bowler, Shaun, David Denemark and Todd Donovan (2003) 'Populist Parties and Support for Direct Democracy'. Paper presented at the Australasian Political Studies Association Conference, Hobart, Tasmania.

Bowler, Shaun, Todd Donovan and Jeffrey A. Karp (2002) 'When Might Institutions Change? Elite Support for Direct Democracy in Three Nations', Political Research Quarterly 55: 731-54.

Bowler, Shaun, Todd Donovan and Jeffrey A. Karp (2006) 'Why Politicians Like Electoral Institutions: Self-interest, Values and Ideology', Journal of Politics 68: 434-46.

Budge, Ian (1996) The New Challenge of Direct Democracy. Cambridge: Polity Press.

Butler, David and Austin Ranney (1994) Referendums Around the World: The Growing Use of Direct Democracy. Washington, DC: AEI Press. 
Canovan, Margaret (1999) 'Trust the People! Populism and the Two Faces of Democracy', Political Studies 46: 2-16.

Craig, Stephen, Amie Kreppel and James Kane (2001) 'Public Opinion and Support for Direct Democracy: a Grassroots Perspective', in M. Mendelsohn and A. Parkin (eds) Referendum Democracy: Citizens, Elites and Deliberation in Referendum Campaigns, pp. 25-46. New York: Palgrave.

Cronin, Thomas E. (1989) Direct Democracy: The Politics of Initiative, Referendum, and Recall. Cambridge, MA: Harvard University Press.

Dalton, Russell (1984) 'Cognitive Mobilization and Partisan Dealignment in Advanced Industrial Democracies', Journal of Politics 46: 264-84.

Dalton, Russell (1996) Citizen Politics: Public Opinion and Political Parties in Advanced Industrial Democracies. Chatham, NJ: Chatham House.

Dalton, Russell J., Wilhelm Burklin and Andrew Drummond (2001) 'Public Opinion and Direct Democracy', Journal of Democracy 12: 141-53.

Donovan, Todd, Caroline J. Tolbert and Daniel A. Smith (2005) 'Voter Mobilization by Ballot Initiatives'. Mimeo. Department of Political Science, Western Washington University.

Gallagher, Michael and Pier Vincenzo Uleri (1996) The Referendum Experience in Europe. Basingstoke: Macmillan.

Gilljam, Mikael, Pertti Pesonen and Ola Listhaug (1998) 'The Referendum in Representative Democracies', in Anders Todal Jenssen, Pertti Pesonen and Mikael Gilljam (eds) To Join or Not to Join: Three Nordic Referendums on Membership in the European Union, pp. 284-306. Oslo: Scandinavian University Press.

Hagen, Michael and Edward Lascher (2004) 'The Popular Appeal of Direct Democracy'. Paper presented at the American Political Science Association Meeting, Washington, DC.

Hagle, Timothy M. and Glen E. Mitchell (1992) 'Goodness of Fit Measures for Probit and Logit', American Journal of Political Science 36: 762-84.

Hibbing, John and Elizabeth Theiss-Morse (2001) 'Process Preferences and American Politics: What the People Want Government To Be', American Political Science Review 95: 145-53.

Hug, Simon (2002) Voices of Europe: Citizens, Referendums, and European Integration. Lanham, MD: Rowan \& Littlefield.

Inglehart, Ronald (1977) Silent Revolution: Changing Values and Political Styles Among Western Publics. Princeton, NJ: Princeton University Press.

Inglehart, Ronald (1990) Culture Shift in Advanced Industrial Society. Princeton, NJ: Princeton University Press.

Ingelhart, Ronald (1999) 'Postmodernization Erodes Respect for Authority, but Increases Support for Democracy', in Pippa Norris (ed.) Critical Citizens: Global Support for Democratic Governance, pp. 236-56. Oxford: Oxford University Press.

Karp, Jeffrey and Peter Aimer (2002) 'Direct Democracy on Trial: The CitizensInitiated Referendums', in Jack Vowles, Peter Aimer, Jeffrey Karp, Raymond Miller and Ann Sullivan (eds) Proportional Representation on Trial: The 1999 New Zealand General Election and the Fate of MMP, pp. 146-59. Auckland: Auckland University Press.

Karp, Jeffrey A., Susan A. Banducci and Shaun Bowler (2003) 'To Know It Is to Love It? Satisfaction with Democracy in the European Union', Comparative Political Studies 36: 271-92. 
Laycock, David (1990) Populism and Democratic Thought in the Canadian Prairies, 1910-1845. Toronto, ON: University of Toronto Press.

LeDuc, Lawrence (2003) The Politics of Direct Democracy: Referendums in Global Perspective. Peterborough, ON: Broadview Press.

Lupia, Arthur (1994) 'Shortcuts versus Encyclopedias: Information and Voting Behavior in California Insurance Reform Elections', American Political Science Review 88: 63-76.

Mendelsohn, Matthew and Andrew Parkin (2001) 'Introducing Direct Democracy in Canada', Choices 7: 3-35

Norris, Pippa (ed.) (1999) Critical Citizens: Global Support for Democratic Governance. Oxford: Oxford University Press.

O’Neill, Brenda (2001) 'Generational Patterns in the Political Opinions and Behaviour of Canadians', Policy Matters 2: 5-11.

Pesonen, Pertti (ed.) (1994) Suomen EU-kansanäänestys 1994: raportti äänestäjien kannanotoista. (The 1994 EU referendum in Finland). Helsinki: Ulkoasiainministeriö, eurooppatiedotus.

Pharr, Susan J. and Robert D. Putnam (2000) Disaffected Democracies: What's Troubling the Trilateral Countries? Princeton, NJ: Princeton University Press.

Ruff, Norman (1993) 'Institutionalizing Populism in British Columbia', Canadian Parliamentary Review 16: 24-32.

Scarrow, Susan E. (1999) 'Parties and the Expansion of Direct Democracy: Who Benefits?', Party Politics 5: 341-62.

Scarrow, Susan E. (2001) 'Direct Democracy and Institutional Change: A Comparative Investigation', Comparative Political Studies 34: 651-65.

Setala, Maija (1999) 'Referendums in Western Europe - A Wave of Direct Democracy?', Scandinavian Political Studies 22: 327-40.

TODD DONOVAN is Professor of Political Science at Western Washington University. He has co-authored several books, including two on direct democracy. Some of his recent research examines how referendums affect voting in candidate elections; popular support for multipartyism in the USA (Social Science Quarterly); elite attitudes about electoral institutions (Journal of Politics); and the relationships between electoral losses and how citizens reason about electoral institutions.

ADDRESS: Department of Political Science, Western Washington University, Bellingham, WA 98225, USA. [email: donovan@cc.wwu.edu]

JEFFREY A. KARP is Senior Lecturer in Politics at the University of Exeter and Senior Research Fellow in the School of Business, Public Administration and Technology at the University of Twente. His research focuses on comparative political behaviour, examining such topics as political mobilization and turnout, minority representation, political attitudes, and elite and mass responses to institutional reform. His most recent articles appear in Journal of Politics, British Journal of Political Science and Electoral Studies.

ADDRESS: Department of Politics, Amory Building, Rennes Drive, Exeter, Devon, UK EX4 4RJ. [email: j.karp@exeter.ac.uk] 